\title{
ANALISIS PENGARUH PENERAPAN GOOD CORPORATE GOVERNANCE TERHADAP KINERJA PERUSAHAAN
}

\author{
Rio Novianto Rossi; Rosinta Ria Panggabean \\ Jurusan Akuntansi, Fakultas Ekonomi dan Komunikasi, BINUS University \\ Jln. K.H. Syahdan No. 9, Palmerah, Jakarta Barat 11480 \\ Rosinta_Ria_Panggabean@binus.ac.id
}

\begin{abstract}
This study describes the relationship between corporate governance with corporate performance and learns about the development and implementation of GCG in Indonesia. This study uses regression analysis to determine whether corporate governance has a positive influence. Sampling of Corporate Governance Perception Index (CGPI) for 2006 to 2009 from The Indonesian Institute for Corporate Governance (IICG) was used to measure the influence of corporate governance with Tobin's $Q$ on the performance of the enterprise market and Return On Equity (ROE) was used to measure the operational performance of the company. This study used a sample of 40 companies surveyed by IICG from 2006 to 2009 and included in the top 10 corporate governance ranking index released by IICG and the companies' financial reporting are also listed on the BEI (Bursa Efek Indonesia) as well. The sampling method is purposive sampling. The result of this study indicate that there is no significant relationship between corporate governance with Tobin's Q (market performance) but there is a significant positive relationship between corporate governance with ROE (operational performance).
\end{abstract}

Keywords: corporate governance, Tobin's Q, ROE, corporate performance

\begin{abstract}
ABSTRAK
Penelitian ini bertujuan untuk menjelaskan hubungan antara corporate governance dengan kinerja perusahaan dan mengetahui perkembangan dan penerapan GCG di Indonesia. Penelitian ini menggunakan analisis regresi berganda untuk mengetahui apakah corporate governance memiliki pengaruh positif. Pengambilan sampel Corporate Governance Perception Index (CGPI) untuk 2006 sampai 2009 dari The Indonesian Institute for Corporate Governance (IICG) digunakan untuk mengukur pengaruh corporate governance dengan Tobin's Q pada kinerja pasar perusahaan dan Return On Equity (ROE) digunakan untuk mengukur kinerja operasional perusahaan. Penelitian ini menggunakan sampel sebanyak 40 perusahaan yang mengikuti survey IICG dari tahun 2006 hingga 2009 yang termasuk dalam 10 besar pemeringkatan indeks corporate governance yang dikeluarkan IICG dan laporan keuangan perusahaannya terdaftar di BEI (Bursa Efek Indonesia) juga. Metode pengambilan sampel yaitu purposive sampling. Hasil dari penelitian ini menunjukkan bahwa tidak terdapat hubungan signifikan antara corporate governance dengan Tobin's $Q$ (kinerja pasar) tetapi terdapat hubungan positif signifikan antara corporate governance dengan ROE (kinerja operasional).
\end{abstract}

Kata kunci: corporate governance, Tobin's Q, ROE, kinerja perusahaan 


\section{PENDAHULUAN}

Corporate Governance merupakan tata kelola perusahaan yang menjelaskan hubungan pihakpihak yang berpartisipasi dalam pengelolaan dan kinerja perusahaan. Isu mengenai corporate governance mengemuka di Indonesia pada tahun 1998 di saat Indonesia mengalami krisis berkepanjangan. Banyak pihak seperti pengamat ekonomi, investor, dan kalangan akademisi yang mengatakan bahwa lamanya proses pemulihan dari krisis ini disebabkan sangat lemahnya penerapan Good Corporate Governance yang diterapkan oleh perusahaan-perusahaan di Indonesia. Sejak saat itu, pemerintah dan investor mulai memberikan perhatian yang signifikan terhadap GCG. Ciri utama dari lemahnya corporate governance adalah adanya tindakan-tindakan yang mementingkan diri sendiri dengan mengabaikan kepentingan investor, maka akan menyebabkan jatuhnya harapan para investor tentang pengembalian atas investasi yang telah mereka tanamkan.

Di era globalisasi ini, Good Corporate Governance (GCG) sudah diterapkan oleh banyak perusahaan di Indonesia. Good Corporate Governance (GCG) secara definitive adalah sistem yang mengatur dan mengendalikan perusahaan yang menciptakan nilai tambah (value added) untuk semua stakeholders (Monks, 2003). Ada dua hal yang ditekankan dalam konsep ini. Pertama, pentingnya hak pemegang saham untuk memperoleh informasi dengan benar dan tepat pada waktunya dan kedua, kewajiban perusahaan untuk melakukan pengungkapan (disclosure) secara akurat, tepat waktu, transparan terhadap semua informasi kinerja perusahaan, kepemilikan, dan stakeholders.

Di Indonesia, terdapat institusi yang menilai sejauh mana penerapan corporate governance terhadap perusahaan-perusahaan yaitu The Indonesian Institute for Corporate Governance (IICG). Riset yang dilakukan IICG tersebut dinilai dari 13 aspek yaitu komitmen, transparansi, akuntabilitas, responsibilitas, independensi, keadilan, kompetensi, kepemimpinan, kemampuan bekerja sama, visi misi dan tata nilai, nilai moral dan etika, strategi dan kebijakan, serta budaya. Riset tersebut dilakukan sejak tahun 2001 dan dilaksanakan tiap tahun pada bulan April-November. Menurut IICG sendiri, riset tersebut bertujuan untuk memacu perusahaan dalam meningkatkan kualitas penerapan corporate governance melalui perbaikan yang berkesinambungan (continuous improvement) dengan melaksanakan evaluasi dan melakukan studi banding (benchmarking). Penelitian ini dilakukan untuk mengetahui dan meneliti hubungan antara good corporate governance dengan kinerja perusahaan.

Penelitian ini dilakukan mengacu pada penelitian Sabrinna (2010). Pertanyaan- pertanyaan yang dikemukakan pada penelitian ini yaitu: (1) apakah Good Corporate Governance mempengaruhi kinerja pasar perusahaan (Tobin's Q) secara positif; (2) apakah Good Corporate Governance mempengaruhi kinerja operasional perusahaan (Return on Equity) secara positif; (3) apakah variabel kontrol seperti komposisi aktiva, ukuran perusahaan, dan growth opportunity juga berkontribusi dalam mempengaruhi baik kinerja operasional (ROE) maupun kinerja pasar (Tobin’s Q) perusahaan secara positif pula.

\section{Kerangka Teori dan Literatur}

Menurut Monks (2003) corporate governance adalah sistem yang mengatur dan mengendalikan perusahaan yang menciptakan nilai tambah (value added) untuk semua stakeholders. Ada dua hal yang ditekankan dalam konsep ini. Pertama, pentingnya hak pemegang saham untuk memperoleh informasi dengan benar dan tepat pada waktunya dan kedua, kewajiban perusahaan untuk melakukan pengungkapan (disclosure) secara akurat, tepat waktu, transparan terhadap semua informasi kinerja perusahaan, kepemilikan dan stakeholder. 
Menurut The Indonesian Institute for Corporate Governance (2011) corporate governance adalah struktur, sistem dan proses yang digunakan oleh organ-organ perusahaan sebagai upaya untuk memberikan nilai tambah perusahaan secara berkesinambungan dalam jangka yang panjang.

Menurut Organization for Economic Cooperation and Development (OECD) ada 5 prinsip dasar corporate governance. The rights of shareholders. Kerangka kerja corporate governance seharusnya melindungi hak-hak pemegang saham. Pemegang saham memiliki hak untuk berpartisipasi dan hak untuk mengetahui keputusan-keputusan mengenai perubahan pada perusahaan secara fundamental seperti: 1) perubahan atas peraturan, atau anggaran yang mengatur pendirian, dan dokumen-dokumen perusahaan; 2) wewenang pada additional shares; dan 3) transaksi besar/luar biasa yang berakibat pada penjualan perusahaan.

The equitable treatment of shareholders. Kerangka kerja corporate governance seharusnya memastikan perlakuan yang adil bagi semua pemegang saham, termasuk pemegang saham asing dan minoritas. Semua pemegang saham seharusnya memiliki kesempatan untuk mendapatkan ganti rugi atas pelanggaran hak-hak mereka.

The role of stakeholders. Kerangka kerja corporate governance seharusnya mengakui hak-hak para pemangku kepentingan seperti yang ditetapkan oleh hukum dan mendorong kerjasama aktif antara perusahaan dan para pemangku kepentingan (stakeholders) dalam menciptakan kesejahteraan, pekerjaan, dan keberlanjutan finansial perusahaan.

Disclosure and transparency. Kerangka kerja corporate governance seharusnya memastikan pengungkapan yang akurat dan tepat waktu dibuat berdasarkan material yang berhubungan dengan perusahaan, termasuk situasi keuangan, kinerja, kepemilikan, dan tata kelola perusahaan tersebut. Pengungkapan seharusnya termasuk, tetapi tidak dibatasi, material berikut: (1) hasil kegiatan operasi dan finansial perusahaan; (2) tujuan-tujuan perusahaan; (3) kepemilikan saham mayoritas dan hak voting; (4) anggota dewan dan eksekutif kunci serta pemberian gajinya; (5) material dari faktor risiko yang dapat diduga; (6) isu material mengenai pekerja dan stakeholders.

The responsibility of the board. Kerangka kerja corporate governance seharusnya memastikan pedoman strategis perusahaan, pengawasan efektif manajemen oleh dewan, dan akuntabilitas dewan kepada perusahaan dan pemegang saham.

Penerapan Good Corporate Governance menurut Monks (2003) memiliki beberapa manfaat yaitu: (1) mengurangi agency cost yang merupakan biaya yang harus ditanggung pemegang saham karena penyalahgunaan wewenang sebagai akibat pendelegasian wewenang kepada pihak manajemen; (2) mengurangi biaya modal (cost of capital) sebagai dampak dari menurunnya tingkat bunga atas dana dan sumber daya yang dipinjam oleh perusahaan seiring dengan turunnya tingkat resiko perusahaan; dan (3) menciptakan dukungan para stakeholder dalam lingkungan perusahaan tersebut terhadap keberadaan dan berbagai strategi dan kebijakan yang ditempuh perusahaan.

\section{Perkembangan Good Corporate Governance di Indonesia}

Pemerintah Indonesia telah melakukan upaya untuk mendorong penerapan Good Corporate Governance di Indonesia, antara lain pada tahun 1999 dengan membentuk Komite Nasional Kebijakan Corporate Governance (KNKCG) yang telah mengeluarkan Pedoman Good Corporate Governance. Pada tahun 2004, KNKCG diubah menjadi Komite Nasional Kebijakan Governance (KNKG). Lalu pada tahun 2006 KNKG menyusun Pedoman Umum Good Corporate Governance Indonesia yang merupakan panduan bagi perusahaan dalam membangun, melaksanakan, dan mengkomunikasikan praktek GCG kepada pemangku kepentingan (stakeholders). Bahkan sejak tahun 2000, Bapepam juga terlibat secara aktif mendorong penerapan prinsip-prinsip GCG kepada seluruh pelaku pasar di pasar 
modal Indonesia. Sejak tahun 2001 The Indonesian Institute for Corporate Governance (IICG), telah melakukan penelitian tentang proses penerapan GCG di perusahaan publik. Hasil risetnya berupa pemeringkatan 10 besar perusahaan yang telah menerapkan GCG.

Tahun 2002, pemerintah Indonesia dalam hal ini kantor kementrian BUMN telah membuat Surat Keputusan Menteri BUMN No. Kep-117/M-MBU/2002 tentang penerapan Good Corporate Governance pada Badan Usaha Milik Negara (BUMN), yang di dalamnya menjabarkan tentang prinsip-prinsip good corporate governance yang sejalan dengan prinsip-prinsip yang dirumuskan oleh OECD.

Pengukuran corporate governance dilakukan oleh IICG berupa Corporate Governance Perception Index (CGPI) yang berisikan skor berupa angka mulai dari 0 sampai 100 yang merupakan hasil survei mengenai penerapan good corporate governance pada perusahaan-perusahaan yang terdaftar di Bursa Efek Indonesia (BEI). CGPI merupakan program riset dan pemeringkatan penerapan good corporate governance di Indonesia pada perusahaan publik.

\section{Kinerja Perusahaan}

Kinerja perusahaan merupakan penentuan ukuran-ukuran tertentu yang dapat mengukur keberhasilan suatu perusahaan dalam menghasilkan laba (Sucipto, 2003). Penilaian kinerja adalah penentuan secara periodik efektivitas operasional suatu organisasi, bagian organisasi dan karyawan berdasarkan sasaran, standar dan kinerja yang telah ditetapkan sebelumnya. Penilaian kinerja perusahaan dapat dilihat dari segi analisis laporan keuangan dan dari segi perubahan harga saham. Penilaian kinerja dimanfaatkan manajer untuk hal-hal seperti: (1) mengelola operasi organisasi secara efektif dan efisien melalui pemotivasian karyawan secara maksimal; (2) membantu pengambilan keputusan yang bersangkutan dengan karyawan seperti promosi, transfer dan pemberhentian; (3) menyediakan kebutuhan pelatihan dan pengembangan karyawan dan untuk menyediakan kriteria seleksi dan evaluasi program pelatihan karyawan; (4) menyediakan umpan balik (feedback) bagi karyawan mengenai bagaimana atasan mereka menilai kinerja mereka; (5) menyediakan suatu dasar bagi distribusi menilai kinerja mereka.

Rasio keuangan merupakan alat utama untuk menganalisa keuangan. Berikut ini adalah beberapa rasio keuangan yang digunakan untuk mengukur kinerja perusahaan (Ang, 1997) yaitu: rasio likuiditas, rasio aktivitas, rasio profitabilitas, rasio solvabilitas (leverage), dan rasio pasar.

Ada dua macam kinerja yang diukur dalam berbagai penelitian yaitu kinerja operasi perusahaan dan kinerja pasar. Kinerja operasi perusahaan diukur dengan melihat kemampuan perusahaan yang tampak pada laporan keuangannya. Untuk mengukur kinerja operasi perusahaan biasanya digunakan rasio profitabilitas. Rasio profitabilitas mengukur kemampuan perusahaan menghasilkan keuntungan pada tingkat penjualan, asset dan modal saham tertentu. Rasio yang sering digunakan adalah ROE dan Tobin's Q.

\section{Return on Equity (ROE)}

Return on Equity (ROE) merupakan rasio antara net profit terhadap total equity. Semakin tinggi ROE menunjukkan semakin efisien perusahaan menggunakan modal sendiri untuk menghasilkan laba atau keuntungan bersih. ROE digunakan untuk mengukur tingkat pengembalian perusahaan atau efektivitas perusahaan di dalam menghasilkan keuntungan dengan memanfaatkan ekuitas (shareholders' equity) yang dimiliki oleh perusahaan. 


\section{Tobin's $Q$}

Ada beberapa rasio untuk mengukur nilai pasar perusahaan, salah satu yang bisa memberikan informasi yang paling baik adalah Tobin's Q. Penelitian Klapper dan Love (2002) menentukan bahwa nilai Tobin's Q merupakan rasio dari harga penutupan saham di akhir tahun buku dikali dengan banyaknya saham yang beredar ditambah nilai buku hutang dibagi dengan total aktiva. Semakin besar nilai rasio Tobin's Q menunjukkan bahwa perusahaan memiliki prospek pertumbuhan yang baik dan memiliki intangible asset yang semakin besar. Hal ini bisa terjadi karena semakin besar nilai pasar aset perusahaan, semakin besar kerelaan investor untuk mengeluarkan pengorbanan yang lebih untuk memiliki perusahaan tersebut.

\section{Penelitian Terdahulu}

Penelitian yang pernah dilakukan oleh beberapa penulis merupakan pengembangan baik dari variabel maupun pengambilan sampel yang digunakan sehingga dalam hasil penelitian yang dilakukan pun memiliki ragam yang berbeda dan tentunya dapat dijadikan sebagai pedoman untuk melakukan penelitian selanjutnya. Tabel berikut merangkum contoh beberapa penelitian terdahulu yang pernah dilakukan.

Tabel 1 Penelitian Terdahulu

\begin{tabular}{|c|c|c|}
\hline Nama / Judul Penelitian & $\begin{array}{c}\text { Pertanyaan Penelitian, Sampel } \\
\text { dan Metode }\end{array}$ & Hasil Penelitian \\
\hline $\begin{array}{l}\text { Anindhita Ira Sabrinna / } \\
\text { Pengaruh Penerapan Corporate } \\
\text { Governance dan Struktur } \\
\text { Kepemilikan terhadap Kinerja } \\
\text { Perusahaan }\end{array}$ & $\begin{array}{l}\text { Pertanyaan penelitian: } \\
\text { 1. Apakah Corporate } \\
\text { Governance mempengaruhi } \\
\text { kinerja pasar (Tobin's Q) } \\
\text { perusahaan secara positif? } \\
\text { 2. Apakah Corporate } \\
\text { Governance mempengaruhi } \\
\text { kinerja operasional (ROE) } \\
\text { perusahaan secara positif? } \\
\text { Apakah struktur kepemilikan } \\
\text { baik secara institusional dan } \\
\text { manajerial mempengaruhi } \\
\text { kinerja perusahaan? } \\
\text { Sampel: } \\
\text { 42 perusahaan manufaktur yang } \\
\text { terdaftar di BEI dan mengikuti } \\
\text { survey CGPI 2002 - 2008 } \\
\text { Metode: } \\
\text { Uji statistik, uji normalitas data, } \\
\text { uji autokorelasi, uji } \\
\text { multikolinearitas, uji } \\
\text { heterokedastisitas dan model } \\
\text { regresi }\end{array}$ & $\begin{array}{l}\text { Tidak terdapat hubungan } \\
\text { signifikan antara corporate } \\
\text { governance dengan Tobin’s Q } \\
\text { (kinerja pasar) tetapi terdapat } \\
\text { hubungan positif signifikan } \\
\text { antara corporate governance } \\
\text { dengan ROE. Sedangkan pada } \\
\text { struktur kepemilikan tidak } \\
\text { terdapat hubungan signifikan } \\
\text { antara kepemilikan manajerial } \\
\text { dan institusional terhadap kinerja } \\
\text { perusahaan, hal ini dikarenakan } \\
\text { bahwa keberadaan manajer dan } \\
\text { pemegang saham kurang } \\
\text { memiliki pengaruh dalam } \\
\text { peningkatan kinerja perusahaan. }\end{array}$ \\
\hline $\begin{array}{l}\text { Siddharta Utama / Tata Kelola } \\
\text { Perusahaan, Pengungkapan, dan } \\
\text { Buktinya di Indonesia }\end{array}$ & $\begin{array}{l}\text { Pertanyaan penelitian: } \\
\text { 1. Apakah tata kelola } \\
\text { perusahaan mempengaruhi } \\
\text { pengungkapan yang } \\
\text { dilakukan oleh perusahaan? } \\
\text { Sampel: } \\
\text { 104 perusahaan yang terdaftar di } \\
\text { BEI tahun } 1998 \text {. }\end{array}$ & $\begin{array}{l}\text { Ditemukan bahwa tingkat } \\
\text { pengungkapan dipengaruhi } \\
\text { secara positif oleh ukuran } \\
\text { perusahaan dan leverage } \\
\text { keuangan. Ukuran perusahaan } \\
\text { dan leverage keuangan } \\
\text { dipengaruhi secara positif oleh } \\
\text { GCG }\end{array}$ \\
\hline Deni Dharmawati Khomsiyah / & Pertanyaan penelitian: & Tidak ada hubungan signifikan \\
\hline
\end{tabular}




\begin{tabular}{|c|c|c|}
\hline Nama / Judul Penelitian & $\begin{array}{l}\text { Pertanyaan Penelitian, Sampel } \\
\text { dan Metode }\end{array}$ & Hasil Penelitian \\
\hline $\begin{array}{l}\text { Pengaruh Penerapan Corporate } \\
\text { Governance terhadap Kinerja } \\
\text { Perusahaan }\end{array}$ & $\begin{array}{l}\text { 1. Apakah corporate } \\
\text { governance mempengaruhi } \\
\text { kinerja pasar (Tobin’s Q) } \\
\text { dan operasional (ROE) dari } \\
\text { perusahaan? } \\
\text { Sampel: } \\
\text { 20 perusahaan yang terdaftar di } \\
\text { BEI dan masuk dalam ranking } \\
\text { CGPI tahun } 2001 \text { - } 2002\end{array}$ & $\begin{array}{l}\text { antara corporate governance } \\
\text { dengan Tobin’s Q. Tetapi ada } \\
\text { hubungan signifikan positif } \\
\text { antara corporate governance } \\
\text { dengan Return On Equity (ROE). } \\
\text { Artinya implementasi corporate } \\
\text { governance yang baik } \\
\text { mempengaruhi kinerja } \\
\text { operasional tetapi pasar tidak } \\
\text { merespon implementasinya } \\
\text { secepat mungkin. }\end{array}$ \\
\hline $\begin{array}{l}\text { Yunita Heryani Mintara / } \\
\text { Pengaruh Implementasi } \\
\text { Corporate Governance terhadap } \\
\text { Pengungkapan Informasi }\end{array}$ & $\begin{array}{l}\text { Pertanyaan penelitian: } \\
\text { 1. Apakah corporate } \\
\quad \text { governance mempengaruhi } \\
\quad \text { pengungkapan informasi } \\
\quad \text { dalam laporan tahunan? } \\
\text { Sampel: } \\
50 \text { perusahaan yang terdaftar di } \\
\text { BEI dan masuk dalam ranking } 10 \\
\text { besar CGPI periode } 2002 \text { - } 2006 \\
\text { Metode: } \\
\text { Statistik deskriptif, uji } \\
\text { normalitas, uji asumsi klasik, dan } \\
\text { analisis regresi berganda }\end{array}$ & $\begin{array}{l}\text { Dapat disimpulkan bahwa } \\
\text { implementasi Corporate } \\
\text { Governance bepengaruh secara } \\
\text { signifikan terhadap tingkat } \\
\text { pengungkapan informasi suatu } \\
\text { perusahaan. Perusahaan dengan } \\
\text { indeks Corporate Governance } \\
\text { tinggi akan mengungkapkan } \\
\text { informasi lebih baik dalam } \\
\text { laporan keuangan perusahaan. }\end{array}$ \\
\hline $\begin{array}{l}\text { Yan Leung-Cheung et al. / Does } \\
\text { Corporate Governance Predict } \\
\text { Future Performance? Evidence } \\
\text { from Hong Kong }\end{array}$ & $\begin{array}{l}\text { Pertanyaan penelitian: } \\
\text { 1. Apakah corporate } \\
\text { governance dapat } \\
\text { memprediksi kinerja pasar } \\
\text { perusahaan di masa depan? } \\
\text { Sampel: } \\
510 \text { perusahaan yang terdaftar di } \\
4 \text { bursa saham Hong Kong } \\
\text { periode } 2002 \text { - } 2005\end{array}$ & $\begin{array}{l}\text { Perusahaan yang melakukan } \\
\text { peningkatan pada kualitas } \\
\text { corporate governance } \\
\text { menunjukkan peningkatan } \\
\text { penilaian pasar, dan sebaliknya. } \\
\text { Selain itu, dampaknya lebih } \\
\text { besar bagi perusahaan yang } \\
\text { termasuk dalam MSCI Index } \\
\text { atau berafiliasi dengan Cina. } \\
\text { Hasilnya menunjukkan bukti } \\
\text { yang mendukung bahwa good } \\
\text { corporate governance dapat } \\
\text { memprediksi penilaian pasar di } \\
\text { masa depan. }\end{array}$ \\
\hline
\end{tabular}

\section{Pengembangan Hipotesis}

Teori keagenan dapat menjelaskan bagaimana pihak-pihak yang terlibat dalam perusahaan akan berperilaku, karena pada dasarnya mereka memiliki kepentingan yang berbeda. Dengan kepentingan yang berbeda, antara agen dan prinsipal terjadi konflik yang potensial. Adanya konflik tersebut mengakibatkan perlunya check dan balance untuk mengurangi kemungkinan penyalahgunaan kekuasaan oleh manajemen.

Adanya prinsip-prinsip corporate governance seperti transparency, accountability, responsibility dan fairness yang dilakukan oleh perusahaan dan mekanisme corporate governance dapat meminimalisasi konflik kepentingan antara manajer dan para pemegang saham perusahaan. Berdasarkan teori keagenan, dengan adanya good corporate governance, manajer dapat diawasi dengan baik dan agency cost dapat dikurangi. Corporate gorvernance juga memberikan suatu struktur 
yang memfasilitasi penentuan sasaran-sasaran dari suatu perusahaan, dan sebagai sarana untuk menentukan teknik monitoring (pengawasan) kinerja (Khomsiyah, 2004).

Penelitian yang dilakukan oleh Hastuti (2005) menemukan bahwa terdapat hubungan positif antara corporate governance yang diproksikan dengan transparansi dengan kinerja perusahaan yang diukur dengan menggunakan Tobin's Q. Hal ini didukung oleh penelitian Klapper dan Love (2002) yang menemukan adanya hubungan positif antara corporate governance dengan kinerja perusahaan yang diukur dengan Tobin's Q.

Kinerja pasar dapat diukur dengan Tobin's Q. ROE mengukur kemampuan perusahaan menghasilkan laba berdasarkan modal saham tertentu. Tobin's Q membandingkan antara nilai pasar perusahaan dengan replacement cost aset perusahaan. Semakin besar nilai rasio Tobin's Q menunjukkan bahwa perusahaan memiliki prospek pertumbuhan yang baik dan memiliki intangible asset yang semakin besar (Sukamulja, 2004). Karena semakin besar nilai pasar aset perusahaan, semakin besar juga kerelaan investor untuk mengeluarkan pengorbanan yang lebih untuk memiliki perusahaan tersebut. Bredey dan Myers dalam Sukamulja (2004) menyebutkan bahwa perusahaan dengan nilai Q yang tinggi biasanya memiliki brand image perusahaan yang sangat kuat, sedangkan perusahaan yang memiliki Q yang rendah umumnya berada pada industri yang sangat kompetitif atau industri yang mulai mengecil.

Maka berdasarkan referensi hasil penelitian di atas, penulis dapat menarik hipotesis (dugaan) alternative yang dapat dinyatakan sebagai berikut:

H1a: Adanya pengaruh positif good corporate governance terhadap kinerja perusahaan (Tobin's Q). H1b: Adanya pengaruh positif good corporate governance terhadap kinerja perusahaan (ROE).

\section{METODE}

Objek penelitian ini adalah perusahaan-perusahaan yang masuk dalam peringkat 10 besar CGPI dan juga terdaftar di Bursa Efek Indonesia (BEI). Data diambil dengan metode purposive sampling. Ada tiga kriteria yang digunakan yaitu perusahaan tercatat dalam BEI, menerbitkan laporan keuangan tahunan 2006-2009, dan menjadi peserta CGPI. Sumber data yang digunakan adalah data sekunder (kuantitatif) yang diperoleh dari BEI berupa laporan keuangan perusahaan yang masuk peringkat 10 besar CGPI. Teknik analisis data yang digunakan adalah analisis regresi berganda dengan metode penggabungan atau pooling data. Selain statistik deskriptif dilakukan uji asumsi klasik serta uji hipotesis.

Statistik deskriptif adalah statistik yang memberikan gambaran atau deskripsi suatu data yang dilihat dari rata-rata, standar deviasi, variance, maksimum, minimum, kurtosis, skewness (Ghozali, 2005). Statistik deskriptif mendeskripsikan data menjadi sebuah informasi yang lebih jelas dan mudah dipahami.

Pengujian regresi linier berganda dapat dilakukan setelah model dari penelitian ini memenuhi syarat-syarat yaitu lolos dari asumsi klasik. Syarat-syarat yang harus dipenuhi adalah data tersebut harus terdistribusikan secara normal, tidak mengandung multikolinearitas dan heterokedastisitas. Untuk itu sebelum melakukan pengujian regresi linier berganda perlu dilakukan lebih dahulu pengujian asumsi klasik, yang terdiri dari: uji normalitas data, uji multikolinearitas, uji heterokedastisitas, uji autokorelasi.

Uji hipotesis dilakukan dengan dua cara yaitu uji hipotesis secara parsial (uji t) serta uji hipotesis secara serempak (uji f). Uji t dilakukan untuk menguji tingkat signifikansi pengaruh variabel 
independen terhadap variabel dependen secara parsial. Uji F digunakan untuk menguji pengaruh variabel bebas secara bersama-sama atau simultan terhadap variabel terikat.

Variabel independen merupakan variabel yang mempengaruhi atau menjadi sebab perubahan atau timbulnya variabel dependen. Variabel independen penelitian ini adalah good corporate governance yang diukur dengan indeks CGPI dari hasil survei IICG. Variabel dependen penelitian ini adalah kinerja perusahaan. Dalam penelitian ini, kinerja perusahaan diukur dengan menggunakan Tobin's Q sebagai ukuran penilaian pasar dan Return on Equity (ROE) sebagai ukuran kinerja operasional perusahaan. Variabel kontrol merupakan variabel yang dikendalikan atau dibuat konstan sehingga hubungan variabel independen terhadap variabel dependen tidak dipengaruhi oleh faktor luar yang tidak diteliti. Variabel corporate governance memiliki kemungkinan untuk secara endogen ditentukan oleh berbagai faktor. Berbagai variabel yang secara teori menentukan penerapan corporate governance di perusahaan, yaitu:

Komposisi aktiva perusahaan. Perusahaan yang memiliki aktiva tak berwujud dan aktiva lancar yang besar cenderung untuk menerapkan corporate governance yang lebih ketat. Hal ini dikarenakan aktiva lancar dan aktiva tak berwujud lebih mudah diselewengkan dibandingkan dengan aktiva tetap berwujud. Hal ini disebabkan aktiva berwujud mudah dimonitor dan sulit untuk dicuri. Dengan demikian, korelasi antara proporsi aktiva tetap dengan corporate governance akan negatif (Klapper dan Love, 2002; Himmelberg, dkk., 1999; Himmelberg, Hubbard dan Love, 2001). Penelitian ini memasukkan komposisi aktiva sebagai variabel kontrol untuk memastikan bahwa hubungan corporate governance dengan kinerja tidak disebabkan oleh heterogenitas komposisi aktiva. Komposisi aktiva diukur dengan menggunakan rasio antara aktiva tetap terhadap total penjualan.

Asset $=$ Aktiva Tetap $/$ Penjualan

Kesempatan pertumbuhan (Growth Opportunity). Perusahaan yang memiliki pertumbuhan tinggi pada umumnya membutuhkan dana eksternal untuk melakukan ekspansi sehingga mendorong perusahaan untuk melakukan perbaikan dalam penerapan corporate governance dalam rangka untuk menurunkan biaya modal (La Porta, dkk., 1999; Klapper dan Love, 2002; Himmelberg, dkk., 1999; Himmelberg, dkk., 2001). Jika nilai Tobin's Q lebih tinggi untuk perusahaan yang memiliki kesempatan tumbuh tinggi, hal ini bisa disebabkan adanya endogenitas pada variabel corporate governance dalam asosiasi antara corporate governance dengan kinerja. Penelitian ini memasukkan variabel kesempatan pertumbuhan sebagai variabel kontrol dengan menggunakan rumus sebagai berikut:

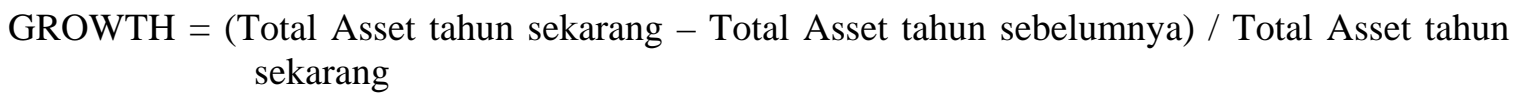

Ukuran perusahaan. Pengaruh ukuran perusahaan terhadap corporate governance masih belum jelas arahnya. Perusahaan besar dapat memiliki masalah keagenan yang lebih besar sehingga membutuhkan corporate governance yang lebih baik. Di sisi lain, perusahaan kecil bisa memiliki kesempatan bertumbuh yang tinggi, sehingga membutuhkan dana eksternal, dan seperti argumen di atas, membutuhkan mekanisme corporate governance yang lebih baik. Ukuran perusahaan diukur dengan menggunakan log natural dari penjualan (Klapper dan Love, 2002).

$$
\text { SIZE }=\text { Log Penjualan }
$$

\section{Metode Empiris}

Untuk melakukan analisis data, digunakan analisis regresi untuk mencari ada pengaruh atau tidak corporate governance terhadap kinerja perusahaan dan seberapa besar pengaruhnya dengan model sebagai berikut: 


$$
\begin{aligned}
\text { Kinerja }=\mathrm{b}_{0}+\mathrm{b}_{1} \mathrm{CG} & +\mathrm{b}_{2} \text { Komposisi aktiva }+\mathrm{b}_{3} \text { Kesempatan tumbuh }+\mathrm{b}_{4} \text { Ukuran perusahaan }+\mathrm{e} \\
\text { Keterangan: } \quad \mathrm{b} & =\text { koefisien regresi } \\
\mathrm{CG} & =\text { Corporate Governance } \\
\mathrm{E} & =\text { Standard Error }
\end{aligned}
$$

\section{HASIL DAN PEMBAHASAN}

Corporate Governance Perception Index adalah hasil pemeringkatan atas penerapan Corporate Governance atau survei implementasi Corporate Governance pada perusahaan publik yang tercatat di BEI, yang dilakukan oleh The Indonesian Institute for Corporate Governance (IICG). Dalam penelitian ini jumlah populasi yang ikut disurvei oleh IICG dari tahun 2006 -tahun 2009 berjumlah 94 perusahaan. Banyaknya sampel sebesar 42,5\% dari besar populasi. Penelitian dilakukan terhadap sampel yang terdiri dari 40 perusahaan yang berpartisipasi dalam CGPI berdasarkan peringkat 10 besar tahun 2006-2009. Berikut daftar perusahaan berdasarkan survei IICG tahun 20062009.

Tabel 2 Daftar perusahaan berdasarkan survei IICG tahun 2006 - 2009

\begin{tabular}{llcclc}
\hline No. & \multicolumn{1}{c}{ Nama Perusahaan } & Skor & No. & \multicolumn{1}{c}{ Nama Perusahaan } & Skor \\
\hline & TAHUN 2006 & & & TAHUN 2007 & \\
\hline 1 & Bank Niaga & 89,27 & 1 & Bank Mandiri & 88,66 \\
2 & Medco International & 87,40 & 2 & Bank Niaga & 87,90 \\
3 & Bank Mandiri & 83,66 & 3 & Aneka Tambang & 82,07 \\
4 & Astra International & 83,01 & 4 & Adhi Karya & 81,79 \\
5 & Aneka Tambang & 81,92 & 5 & United Tractors & 81,53 \\
6 & Telekomunikasi Indonesia & 81,30 & 6 & Tambang Batubara Bukit Asam & 80,87 \\
7 & Bank Negara Indonesia & 79,39 & 7 & Astra Graphia & 80,30 \\
8 & Kalbe Farma & 78,70 & 8 & Kalbe Farma & 79,70 \\
9 & Astra Graphia & 78,33 & 9 & Bank Negara Indonesia & 79,46 \\
10 & Apexindo Pratama & 77,58 & 10 & Bank Permata & 78,85 \\
\hline & TAHUN 2008 & & & TAHUN 2009 & \\
\hline 1 & Bank Mandiri & 91,63 & 1 & Bank Mandiri & 90,65 \\
2 & Bank CIMB Niaga & 90,34 & 2 & Telekomunikasi Indonesia & 88,67 \\
3 & United Tractors & 84,37 & 3 & Bank CIMB Niaga & 88,37 \\
4 & Aneka Tambang & 83,68 & 4 & Aneka Tambang & 85,87 \\
5 & Adhi Karya & 82,97 & 5 & United Tractors & 85,44 \\
6 & Tambang Batubatu Bukit Asam & 81,57 & 6 & Tambang Batubara Bukit Asam & 82,27 \\
7 & Krakatau Steel & 80,76 & 7 & Elnusa & 81,74 \\
8 & Indosat & 80,34 & 8 & Bank Negara Indonesia & 81,63 \\
9 & Bank NISP & 79,24 & 9 & Jasa Marga & 81,62 \\
10 & Wijaya Karya & 78,45 & 10 & Asuransi Jasa Indonesia & 81,59 \\
\hline
\end{tabular}


Analisis pertama yang dilakukan adalah dengan menganalisis data dengan menggunakan statistik deskriptif.

Tabel 3 Statistik Deskriptif

\begin{tabular}{lcrrrr}
\hline & N & \multicolumn{1}{c}{ Minimum } & Maximum & \multicolumn{1}{c}{ Mean } & Std. Deviation \\
\hline Corporate_Governance & 40 & 77.58 & 91.63 & 83.0722 & 3.85616 \\
ROE & 40 & 0.05 & 0.59 & 0.1964 & 0.11876 \\
Tobins_Q & 40 & 0.83 & 1.96 & 1.2193 & 0.27066 \\
Komposisi_Aktiva & 40 & 0.0415 & 1.4927 & 0.568725 & 0.3688125 \\
Growth & 40 & 0.0154 & 1.0000 & 0.187140 & 0.1782427 \\
Ukuran_Perusahaan & 40 & 2.7832 & 7.4660 & 5.442193 & 1.5670294 \\
Valid N (listwise) & 40 & & & & \\
\hline
\end{tabular}

Variabel-variabel yang diteliti, dihitung dengan rumus sebagai berikut:

$\begin{array}{lll}\text { ROE } & = & \text { Net Profit } / \text { Total Equity } \\ \text { Tobin's Q } & = & \text { (MVE+DEBT) } / \text { Nilai Buku Total Aktiva } \\ \text { Komposisi Aktiva Perusahaan } & = & \text { Aktiva Tetap / Penjualan } \\ \text { Growt } & = & \text { (Total Asset tahun sekarang }- \text { Total Asset tahun sebelumnya) } \\ & & / \text { Total Asset tahun sekarang }\end{array}$

Keterangan:

MVE = harga penutupan saham di akhir tahun buku x banyaknya saham biasa yang beredar.

DEBT $=$ (utang lancar - aktiva lancar $)+$ nilai buku persediaan + utang jangka panjang

\section{Uji Asumsi Klasik}

Berdasarkan interpretasi hasil uji normalitas dengan menggunakan Tests of Normality Kolmogorov-Smirnov untuk variabel dependen Return on Equity (ROE), diperlihatkan bahwa nilai signifikansi data sebesar 0,08. Taraf signifikansi uji yang ditetapkan adalah 0,05. Dengan demikian, berdasarkan hasil pengujian normalitas dengan Tests of Normality Kolmogorov-Smirnov, terbukti bahwa data variabel dependen ROE berdistribusi normal.

Tabel 4 Uji Normalitas Kolmogorov-Smirnov

\begin{tabular}{lccc}
\hline \multicolumn{4}{c}{ Kolmogorov-Smirnov } \\
\hline & Statistic & df & Sig \\
\hline ROE & .131 & 40 & .080 \\
\hline
\end{tabular}

Uji multikolinieritas dilakukan dengan menghitung nilai variance inflation factor (VIF) dari tiap - tiap variabel independen. Nilai VIF kurang dari 10 menunjukkan bahwa, korelasi antar variabel independen masih bisa ditolerir (Gujarati, 1995). Berdasarkan hasil analisis, tidak ada variabel independen dalam penelitian ini yang memiliki nilai VIF lebih dari sepuluh. Dengan demikian hasil analisis menunjukkan tidak adanya masalah multikolinieritas.

Tabel 5 Uji Multikolinieritas

\begin{tabular}{lc}
\hline \multicolumn{1}{c}{ Variabel } & Variance Inflation Factor (VIF) \\
\hline Corporate Governance & 1,152 \\
Komposisi Aktiva & 1,334 \\
Growth & 1,121 \\
Ukuran Perusahaan & 1,286 \\
\hline
\end{tabular}


Uji autokorelasi dilakukan dengan menghitung nilai Durbin-Watson $d$ statistic. Korelasi serial dalam residual tidak terjadi jika nilai d berada di antara nilai batas dU dan 4-dU. Dengan variabel sebanyak 4 buah dan sampel sebesar 40, nilai dL sebesar 1,285 dan nilai dU sebesar 1,721, maka nilai d harus berada di antara 1,721 dan 2,279 agar tidak mengalami masalah autokorelasi. Hasil analisis menunjukkan nilai d sebesar 1,637 untuk model regresi dengan variabel dependen return on equity dan nilai d sebesar 2,171 untuk model regresi dengan variabel dependen Tobin's Q. Nilai d sebesar 1,637 berada pada daerah tanpa keputusan, yaitu terletak di antara dL dan dU. Dengan demikian untuk model regresi dengan return on equity sebagai variabel dependen tidak dapat dinyatakan apakah model regresi tersebut mengalami autokorelasi atau tidak. Untuk model regresi dengan menggunakan variabel dependen Tobin's Q tidak mengalami masalah autokorelasi.

Tabel 6 Uji Durbin-Watson dengan variabel dependen ROE

\begin{tabular}{cccccc}
\hline Model & $\mathbf{R}$ & RSquare & $\begin{array}{c}\text { Adjusted } \\
\text { R Square }\end{array}$ & $\begin{array}{c}\text { Std. Error of the } \\
\text { Estimate }\end{array}$ & Durbin-Watson \\
\hline 1 & $.262^{\mathrm{a}}$ & .68 & .38 & .12100 & 1.637 \\
\hline
\end{tabular}

Tabel 7 Uji Durbin-Watson dengan variabel dependen Tobin’s Q

\begin{tabular}{cccccc}
\hline Model & $\mathbf{R}$ & RSquare & $\begin{array}{c}\text { Adjusted } \\
\text { R Square }\end{array}$ & $\begin{array}{c}\text { Std. Error of the } \\
\text { Estimate }\end{array}$ & Durbin-Watson \\
\hline 1 & $.378^{\mathrm{a}}$ & .143 & .045 & .26445 & 2.171 \\
\hline
\end{tabular}

Uji Heterokedastisitas dilakukan dengan menggunakan uji Glejser. Dengan menggunakan uji Glejser, nilai absolute residual diregresikan pada tiap-tiap variabel independen. Masalah heteroskedastisitas terjadi jika ada variabel yang secara statistik signifikan. Model regresi dengan variabel dependen return on equity, variabel independen corporate governance, dan variabel-variabel kontrol tidak mengalami masalah heterokedastisitas. Begitu pula model regresi dengan menggunakan variabel dependen Tobin's Q. Hasil uji heterokedastisitas model regresi dengan menggunakan variabel dependen Tobin’s Q dan ROE disajikan pada tabel 8 dan tabel 9.

Tabel 8 Uji heterokedastisitas dengan ROE

\begin{tabular}{|c|c|c|c|c|c|}
\hline \multirow[t]{2}{*}{ Model } & \multicolumn{2}{|c|}{$\begin{array}{l}\text { Unstandardized } \\
\text { Coefficients }\end{array}$} & \multirow{2}{*}{$\begin{array}{c}\begin{array}{c}\text { Standardized } \\
\text { Coefficients }\end{array} \\
\text { Beta } \\
\end{array}$} & \multirow[t]{2}{*}{$\mathbf{t}$} & \multirow[t]{2}{*}{ Sig } \\
\hline & B & Std. Error & & & \\
\hline (Constant) & .191 & .272 & & .701 & .488 \\
\hline Corporate_Governance & -.001 & .003 & -.070 & -.403 & 689 \\
\hline Komposisi_Aktiva & -.012 & .037 & -.060 & -.321 & .750 \\
\hline Growth & .101 & .071 & .245 & 1.429 & .162 \\
\hline Ukuran_Perusahaan & .000 & .009 & -.020 & -.107 & .915 \\
\hline
\end{tabular}

Tabel 9 Uji heterokedastisitas dengan Tobin’s Q

\begin{tabular}{|c|c|c|c|c|c|}
\hline \multirow[t]{2}{*}{ Model } & \multicolumn{2}{|c|}{$\begin{array}{c}\text { Unstandardized } \\
\text { Coefficients }\end{array}$} & \multirow{2}{*}{$\begin{array}{c}\begin{array}{c}\text { Standardized } \\
\text { Coefficients }\end{array} \\
\text { Beta }\end{array}$} & \multirow[t]{2}{*}{$\mathbf{t}$} & \multirow[t]{2}{*}{ Sig } \\
\hline & B & $\begin{array}{l}\text { Std. } \\
\text { Error }\end{array}$ & & & \\
\hline (Constant) & .467 & .509 & & .919 & .365 \\
\hline Corporate_Governance & -.001 & .006 & -.037 & -.217 & .829 \\
\hline Komposisi_Aktiva & -.132 & .070 & -.349 & -1.893 & .067 \\
\hline Growth & -.072 & .133 & -.092 & -.546 & .589 \\
\hline Ukuran_Perusahaan & -.011 & .016 & -.126 & -.693 & .493 \\
\hline
\end{tabular}




\section{Pengujian Hipotesis}

Uji hipotesis dilakukan dengan menggunakan dua model regresi. Model regresi pertama menggunakan return on equity sebagai ukuran kinerja operasional (variabel dependen ROE) sedangkan model regresi kedua menggunakan Tobin's Q sebagai ukuran kinerja pasar. Hasil pengujian pertama menunjukkan bahwa hanya variabel corporate governance yang secara statistik signifikan mempengaruhi return on equity. Sedangkan tidak ada satupun variabel kontrol yang secara statistik signifikan mempengaruhi return on equity. Dengan demikian dapat disimpulkan bahwa hipotesis penelitian didukung yaitu bahwa corporate governance mempengaruhi kinerja operasi perusahaan. Hasil analisis regresi model Tobin's Q menunjukkan bahwa baik variabel corporate governance maupun variabel-variabel kontrol secara statistik tidak mempengaruhi kinerja pasar perusahaan. Dengan demikian, hipotesis yang menyatakan bahwa corporate governance mempengaruhi kinerja pasar (Tobin's Q) perusahaan secara statistik tidak didukung. Berdasarkan hasil perhitungan dengan SPSS, hasil regresi dengan model ROE menunjukkan besarnya adjusted $R$ Square sebesar 0,38, hal ini berarti 38\% variasi kerja operasional perusahaan dijelaskan oleh variasi variabel independen seperti corporate governance, komposisi aktiva perusahaan, growth, dan ukuran perusahaan. Sedangkan sisanya 62\% dijelaskan oleh sebab-sebab lain di luar model. Untuk model Tobin's Q, adjusted R Square sebesar 0,045 atau 4,5\%. Berarti sisanya 95,5\% dijelaskan oleh sebabsebab lain di luar model.

Uji Anova atau F Test untuk model ROE menghasilkan nilai $\mathrm{F}$ hitung sebesar 0,643 dengan tingkat signifikansi 0,036. Untuk model Tobin's Q, F hitung sebesar 1,463 dengan tingkat signifikansi 0,034. Karena probabilitas signifikansi kedua model tersebut lebih kecil dari 0,05 maka model regresi ROE dan Tobin's Q keduanya dapat digunakan untuk memprediksi kinerja. Atau dengan kata lain, variabel corporate governance, komposisi aktiva perusahaan, growth, dan ukuran perusahaan berpengaruh terhadap kinerja operasional perusahaan ROE dan kinerja pasar (Tobin’s Q).

Dari uji t dapat diketahui, tingkat signifikansi corporate governance terhadap variabel dependen ROE sebesar 0,043 yang berarti berada di bawah tingkat signifikan 0,05. Sedangkan tingkat signifikansi corporate governance terhadap variabel dependen Tobin's Q sebesar 0,053 yang berarti melebihi tingkat signifikan 0,05. Sedangkan variabel-variabel kontrol pada uji t baik melalui model ROE dan Tobin's Q, semuanya memiliki nilai signifikansi melebihi 0,05 yang berarti bahwa variabel kontrol tersebut tidak signifikan dan tidak mempengaruhi kinerja. Dari uji t dapat dijelaskan bahwa corporate governance yang diukur dengan CGPI memiliki pengaruh terhadap kinerja operasional (ROE) perusahaan sedangkan corporate governance tidak memiliki pengaruh terhadap kinerja pasar (Tobin's Q) perusahaan. Berdasarkan hasil pengujian hipotesis dapat ditarik kesimpulan bahwa corporate governance memiliki keterkaitan dengan kinerja operasi (ROE) perusahaan. Dengan kata lain, penulis mendukung hipotesis H1b yang menyatakan adanya pengaruh positif antara good corporate governance dengan kinerja operasional perusahaan. Variabel corporate governance belum mampu mempengaruhi kinerja pasar (Tobin's Q) perusahaan. Dengan kata lain penulis menolak hipotesis H1a yang menyatakan adanya pengaruh positif antara good corporate governance dengan kinerja pasar (Tobin's Q) perusahaan. Hal ini mungkin dikarenakan respon pasar terhadap implementasi corporate governance tidak bisa secara langsung (immediate) akan tetapi membutuhkan waktu.

Berdasarkan penelitian terdahulu yang dilakukan Sabrinna (2010) dan Khomsiyah (2002), penulis dengan tegas mendukung hipotesis kedua peneliti tersebut dimana kedua peneliti tersebut menemukan adanya pengaruh positif penerapan good corporate governance terhadap kinerja operasional perusahaan yang diukur melalui Return On Equity sedangkan tidak ditemukan adanya pengaruh penerapan good corporate governance terhadap kinerja pasar yang diukur dari Tobin's Q. Penelitian ini menolak hipotesis penelitian yang dilakukan oleh Yan Leung-Cheung et al. (2011) yang menemukan adanya pengaruh penerapan good corporate governance terhadap kinerja pasar perusahaan. 


\section{PENUTUP}

Penelitian ini bertujuan untuk menginvestigasi keterkaitan corporate governance yang diterapkan dalam suatu perusahaan dengan kinerja perusahaan yang bersangkutan. Penelitian ini berbeda dengan penelitian-penelitian sebelumnya dalam hal pengukuran variabel corporate governance yang telah disesuaikan dengan kondisi lingkungan bisnis di Indonesia. Hasil analisis menunjukkan bahwa, untuk model regresi dengan return on equity sebagai variabel dependennya, hanya variabel corporate governance yang secara statistik signifikan mempengaruhi return on equity. Sedangkan tidak ada satupun variabel kontrol yang secara statistik signifikan mempengaruhi return on equity. Dengan demikian, dapat disimpulkan bahwa hipotesis penelitian didukung yaitu bahwa corporate governance mempengaruhi kinerja operasi (ROE) perusahaan. Hasil analisis model regresi dengan Tobin's Q sebagai variabel dependennya menunjukkan bahwa baik variabel corporate governance maupun variabel-variabel kontrol secara statistik tidak mempengaruhi kinerja pasar (Tobin's Q) perusahaan. Dengan demikian hipotesis yang menyatakan bahwa corporate governance mempengaruhi kinerja pasar perusahaan secara statistik tidak didukung. Hal ini mungkin dikarenakan respon pasar terhadap implementasi corporate governance tidak bisa secara langsung (immediate) akan tetapi membutuhkan waktu.

\section{Kelemahan Penelitian dan Saran}

Penelitian ini memiliki keterbatasan-keterbatasan yang harus diperhatikan dalam menginterpretasikan hasil penelitian. Keterbatasan pertama adalah terletak pada kurang pastinya keputusan apakah masalah autokorelasi sudah teratasi atau tidak. Nilai Durbin-Watson d statistic untuk model regresi dengan return on equity sebagai variabel dependennya terletak di antara dL dan dU, yaitu daerah tanpa keputusan. Dengan kurang teratasinya masalah autokorelasi dalam model regresi tersebut maka hasil penelitian menjadi kurang robust (kuat dan jelas). Keterbatasan kedua, adalah dalam hal data penelitian kinerja pasar. Data pasar yang digunakan dalam penelitian ini menggunakan data untuk tahun yang sama dengan data corporate governance. Oleh karena pasar membutuhkan waktu untuk bereaksi dan pengungkapan tentang implementasi corporate governance dalam laporan tahunan baru keluar di sekitar bulan Maret tahun berikutnya, maka data kinerja pada periode berikutnya akan lebih baik untuk digunakan.

Selain itu, penelitian ini menggunakan data sekunder dengan melihat nilai indeks Corporate Governance sehingga tidak diketahui secara detail tinggi rendahnya nilai indeks pada setiap kriteria penilaian indeks Corporate Governance. Diharapkan untuk ke depannya, penulis menggunakan data primer sehingga dapat diketahui secara pasti dan mendetail tinggi rendahnya nilai indeks pada corporate governance.

Sampel yang digunakan oleh penulis berjumlah lebih sedikit dibandingkan dengan penelitian acuan (Sabrinna, 2010) yang sebanyak 42 sampel sedangkan penelitian ini hanya 40 sampel. Selain itu, periode yang digunakan penulis hanya 4 tahun dari 2006-2009 sedangkan skripsi acuan 6 tahun dari 2002-2007. Untuk penelitian selanjutnya diharapkan menggunakan data-data primer sehingga hasil penelitian menjadi lebih akurat dan lebih baik. 


\section{DAFTAR PUSTAKA}

Khomsiyah, D. D. (2002). Hubungan corporate governance dan kinerja perusahaan. Jakarta: Universitas Trisakti.

Klapper, L. F., \& Love, I. (2002). Corporate governance, investor protection, and performance in emerging markets. World Bank Working Paper.

KNKCG. 2001. Pedoman Good Corporate Governance ref. 4.0.

Mintara, Y. H. (2008). Pengaruh implementasi corporate governance terhadap pengungkapan informasi. Yogyakarta: Universitas Islam Indonesia.

Monks, R. A. G., \& Minow, N. (2003). Corporate governance. New Jersey: Blackwell.

Organization of Economic Co-operation and Development (OECD). (1999). Principles of Corporate Governance. OECD.

Sabrinna, A. I. (2010). Pengaruh corporate governance dan struktur kepemilikan terhadap kinerja perusahaan. Semarang: Fakultas Ekonomi, Universitas Diponegoro. 